\title{
Lake Orta: a case study (Part 1)
}

\author{
Carla BONACINA and Renato BAUDO \\ (Guest Editors)
}

\section{Preface}

The extraordinary case of industrial pollution in Lake Orta was followed and documented by the Istituto Italiano di Idrobiologia from its very origin in 1926. Many papers were published regarding the effects of the pollution on chemistry and biology of the lake but they were scattered in various scientific journals and in a long time period. Now the time has come to draw the conclusions of our long work and the long history of the lake.

We planned to publish a monographic volume, but technical reasons made it impossible to realise this project. The papers which could have formed the volume will be splitted into issues $60(1)$ and $60(2)$ of Journal of Limnology.

\section{Carla Bonacina \& Renato Baudo}

I took my first sample in Lake Orta on February, $13^{\text {th }} 1968$. I had just obtained my degree in biology and it was my very first independent research work. I remember very well those bottles full of what it seemed like pure tap water, with two little Cyclops swimming in it. No problems of net clogging in Lake Orta in those days. No trace of the little shiver which means that a fish has touched the thermistor sensor: there were no fish at all. But on hot summer days, rare people taking a bath went to our boat and asked us why their eyes were burning. The reason was, very simply, that ammonium content was so high that most probably there was some free ammonia down there. The most perverse aspect of the question was that nobody would believe that such a beautiful lake, with such clear waters, without the ugly algal blooms that infested Lake Maggiore, was nonetheless so heavily polluted. So we got no support from people in our fight to recover the lake.

Many years passed, many things changed, but my samples were still devoid of the lovable creatures I studied. However, in the meantime, new laws made the loadings lighter and the controls stricter, and we could begin thinking about liming the lake. Little by little, my samples were getting richer, both in individuals and in species. Now if you go for a walk along the shore, you can see fish anglers fishing. And catching fish, too! Music, for a hydrobiologist!

In the course of time, many people joined us to study the unusual environment of Lake Orta, people from Universities of Bologna, Parma, Pavia, Milano, Quebec, from Regional Agencies for the Environment, from the European Research Centre of Ispra...

It is a pleasure now to think of the past and see the long chain of scientists, from Pavesi, De Agostini, Monti, Baldi, Moretti, to our professor Tonolli and Vollenweider, whose efforts provided the basis for our work. And we all, undergraduates, technicians, graduates, are very proud of the results we have obtained.

Carla Bonacina 